\title{
OBSTRUCTION OF THE AIRWAY IN THE NEWBORN BY ASPIRATION OF FOETAL MEMBRANE: A CAȘE REPORT
}

\author{
R. A. Gordon, B.SC., M.D., F.R.C.P.(C), F.F.A.R.C.S., AND \\ JosLyn W. Rogers, M.D., F.R.C.S.(C)
}

OBSTRUCTION OF THE AIRWAY in the newborn infant by aspiration of foetal membrane has not previously been reported in the literature as far as we can determine.

\section{Case Report}

A. woman, para ii, gravida iv, was admitted to hospital in well-established labour with a breech presentation. Labour had progressed normally to full dilatation of the cervix when the foetal heart sounds disappeared. Examination showed a prolapsed loop of cord. The patient was immediately anaesthetized with nitrous oxide/trichlorethylene/oxygen, with the addition of succinylcholine chloride $40 \mathrm{mg}$., for relaxation, and delivery was completed with the utmost despatch, ventilation being maintainèd throughout by intermittent positive pressure.

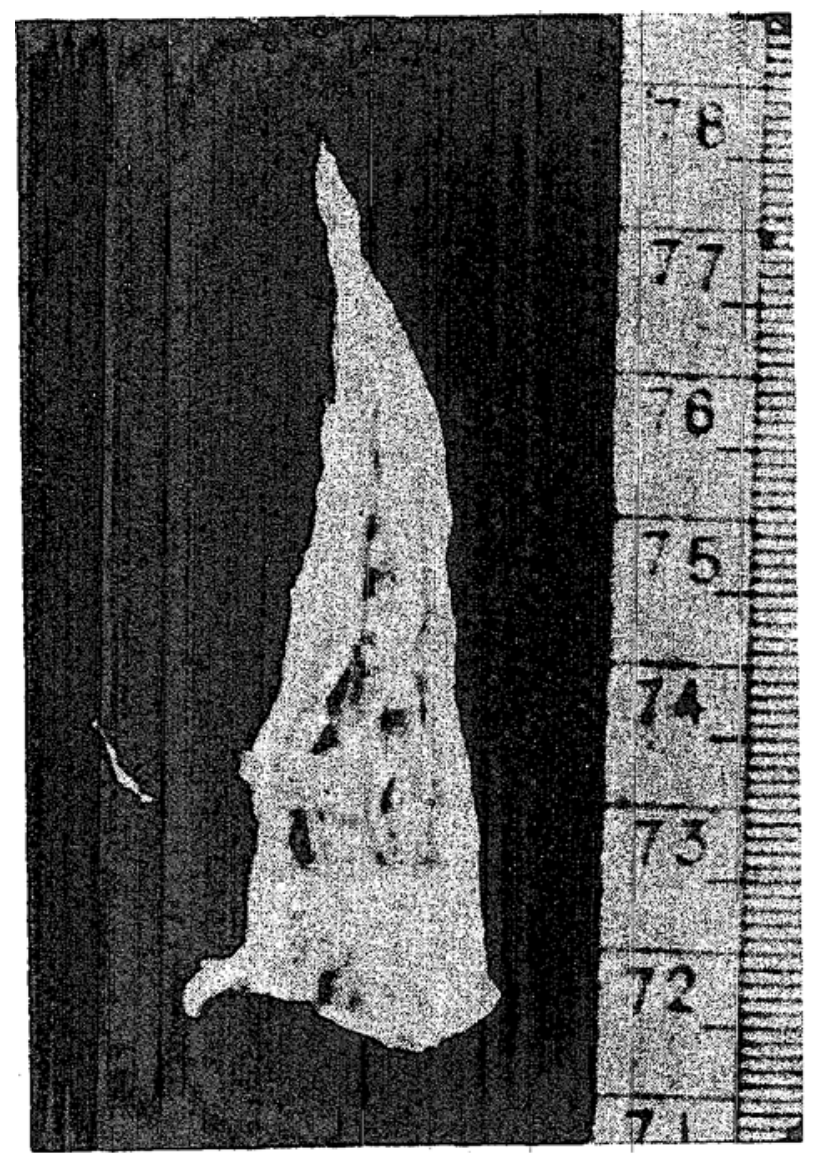

FIGURe 1

On delivery the baby was limp and pale, and no cardiac pulsation was evident. Blood and amniotic fluid were aspirated from the pharynx under direct vision, and immediate intubation of the trachea was done with a Mann's metal tube 
(1). Brief suction was applied to the endotracheal tube, and an attempt was made to inflate the lungs with oxygen. The lungs failing to inflate, suction was again applied to the tube and it was withdrawn. A long string of membrane was found impacted into the distal end of the tube. The tube was cleared and reinserted, when the lungs inflated with ease with the Mann Resuscitator $(12 \mathrm{~cm}$. $\mathrm{H}_{2} \mathrm{O}$ pressure). The infant did not survive.

The membrane removed from the trachea measured $5 \times 7 \mathrm{~cm}$. (Fig. 1). ${ }_{\text {. }}$ at thological examination confirmed that it was foctal membrane.

En autant que nous sachions, il n'a jamais été rapporté dans la littérature de cas d'obstruction des voies respiratoires chez le nouveau-né par l'aspiration de membrane fotale.

\section{HISTOIRE DU $\mid$ CAS}

Une femme, para ii, gravida iv, est entré à l'hôpital en travail avec une présentation du siège. Le travail avait été normal jusqu'à la dilatation complète du col, alors que les bruits du cœur fœtal disparurent. L'examen a révélé une procidence du cordon. On a immédiatement sounis la malade à une anesthésie générale avec du protoxide/chloroéthylène/oxygène en ajoutant de la succinylcholine $40 \mathrm{mg}$. pour obtenir du relâchement et l'accouchement a été complété avec célérité, en assurant une ventilation adéquate par une pression positive intermittente.

Après la délivrance, le bébé était flasque et pâle et on ne percevait pas de pulsation. Sous vision directe, nous avons aspiré du liquide amniotique dans le pharynx et nous avons pratiqué une intubation trachéale avec un tube métallique. de Mann. Nous avons pratiqué un peu de succion sur le tube endotrachéal et nous àvons essayé d'insuffler les poumons de l'enfant avec de l'oxygène. Comme les poumons ne pouvaient être gonflés, nous avons appliqué de nouveau la sutuion sur le tube endotrachéal et nous l'avons retiré. Un long filet de membrane obstruait le bout distal du tube. Le tube a été nettoyé et remis en place et les poumons, avec facilité cette fois, ont pu être gonflés avec le resuscitateur de Mann $(12 \mathrm{~cm}$., $\mathrm{H}_{2} \mathrm{O}$ de pression). Malheureusement l'enfant n'a pas survécu.

La membrane enlevée de la trachée mesurait $5 \times 7 \mathrm{~cm}$. (Fig. 1). La pathologie a confirmé qu'il s'agissait de membrane fœtale.

\section{REFERENCE}

1. ManN, J. Resuscitation of the Newborn: A Method and a Machine. Anesth. \& Analg. 83 : 289 (Sept.-Oct., 1954). 